\title{
Valtio ja aikuiskasvatus
}

Osallistuin 5.-8.7.88 valtion ja aikuiskasvatuksen suhdetta käsitelleeseen kansainväliseen konferenssiin Aachenissa Saksan liittotasavallassa. Konferenssissa oli 35 osanottajaa kahdeksastatoista eri maasta. Kielenä oli englanti ja konferenssissa käsiteltiin 26 "paperia".

Olen käyttänyt lähinnä seuraavien henkilöiden konferenssissa esittämiä raportteja tämän kertomuksen kokoamiseen: Lalage Bown, Peter Jarvis, Philip Hopkins, Joachim H. Knoll, Franz Pöggeler, Walter Leirman ja Herbert Zdarzil.

Jo konferenssikutsussa todettiin, että aikuiskasvatus on aina liittynyt kansalliseen ja poliittiseen historiaan. Toisen maailmansodan jälkeen on hallitusten mielenkiinto aikuiskasvatusta kohtaan lisääntynyt, ja riippumattomat yhteisöt (ay-liike, erilaiset vapaat järjestöt, kirkko jne.) ovat menettäneet yhteiskunnallista vaikutusvaltaansa valtiovaltaan verrattuna ja tämä on heijastunut aikuiskasvatuksen kokonaisuuteen.

Aikuiskasvatuksella on aina ollut ja yhä on läheisemmät suhteet puoluepolitiikkaan kuin koulukasvatuksella. Aikuiskasvatus on myös myöntänyt talouselämän lakien ja poliittisten realiteettien pitkälti hallitsevan sitä.

\section{Aikuiskasvatuksen tehtävä}

Kaikki yhteiskunnallinen toiminta pyrkii toteuttamaan tiettyjä arvoja
- niin aikuiskasvatuskin. Aikuiskasvatuksen suhteen on kuitenkin kaksi erilaista perusnäkemystä. Ensimmäisen mukaan aikuiskasvatus on ainoastaan väline, joka toteuttaa esim. valtiovallan (sosialistiset maat) tai järjestön (kuten Ruotsi) arvoja ja päämääriä. Aikuiskasvatuksella ei ole omaa ideologiaa, se on opetusmenetelmiä, päämääriä palvelevia sisältöjä ja tavoitteita sekä toimintajärjestelmiä. Toisen näkemyksen mukaan aikuiskasvatuksella on omia arvoja, jotka perustuvat yleisinhimillisiin perusarvoihin, joita kuitenkin aikuiskasvatus voi kriittisesti tarkastella. Tämän perusnäkemyksen mukaan aikuiskasvatuksessa ovat tärkeitä ihmisoikeuksien edistäminen, itseymmärryksen syventäminen, suvaitsevaisuuden ja demokratian ihanteiden edistäminen. Tähän perusnäkemykseen voidaan liittää myös tieteellisen tiedon popularisointitehtävä.

Länsi-eurooppalaisen aikuiskasvatuksen historiasta esitettiin kolme tosiasiaa:

- aikuiskasvatuksen eräs päätehtävä on ollut yhteiskunnallisen muutoksen edistäminen,

- toisen maailmansodan jälkeen on valtiovallan kontrolli aikuiskasvatuksen suhteen lisääntynyt,

- todennäköisesti valtiovallan lisääntynyt kontrolli vähentää aikuiskasvatuksen pyrkimystä yhteiskunnalliseen muutokseen.
Kuitenkin aikuiskasvatuksen kannalta:

— tulisi pyrkiä säilyttämään yhteiskunnallisen muutoksen tavoite, - yhteiskunnallisen muutoksen tie kulkee taantumuksellisen oikeiston ja vallankumouksellisen vasemmiston tavoitteiden ulko puolella. Tarvitaan vain selviä näkyjä ja palavaa intoa. Tarkoituksena on nimenomaan auttaa ihmisiä toteuttamaan sellaisia muutoksia, joita he itse haluavat joko omassa elämässään tai laajemmin yhteiskunnassa.

\section{Muutokset työmarkkinoilla}

Länsi-Euroopassa on työelämästä tehty $\mathrm{mm}$. seuraavia ennusteita:

- Työ säilyttää keskeisen roolinsa sekä yksityisen ihmisen elämässä että koko yhteiskunnassa.

- Joidenkin ihmisten kohdalla laajentuneen työn käsitteen yhdistäminen ammattitaidon korkeaan laatuun johtaa entistä parempiin mahdollisuuksiin toteuttaa itseään ja elää merkityksellistä elämää työn kautta.

- Työn ja vapaa-ajan uudenlainen integraatio tulee muuttamaan perinteisiä kulttuurimalleja ensi vuosikymmeneltä.

- On ennustettavissa, että valinnanmahdollisuudet työnteon ja vapaa-ajan suhteen lisääntyvät elinaikana tehdyn palkkatyön määrän vähentyessä.

Konferenssissa tuli myös jatku- 
vasti esiin marxilaisuuden lähtökohdat ja ajattelutavat. Ilmeisesti moderni kapitalistinen materialismi paljolti kulkee marxilaisuuden ennakoimaa uraa. Kansantaloudelliset realiteetit ovat yhteiskunnallisen toiminnan perusta, eli tuotantoelämän kehittyminen on se tosiasia, jota pitää kaikin keinoin edistää.

Tuotantoelämän eräs perustekijä on mahdollisimman korkeatasoinen työvoima ja sen lisäämisessä on ammatillisella aikuiskasvatuksella oma keskeinen tehtävä. Tähän yhteiskunnalliseen muutokseen liittyy kaupallistumisen korostaminen ja amerikkalaistumisen leviäminen.

\section{Valtiovallan ja aikuiskasvatuksen suhde}

Valtiovalta suhtautuu aikuiskasvatukseen seuraavin tavoin:

— valtio kieltää (esim. oppositiolta)

- valtio sallii (esim. yritysten oman ammatillisen aikuiskasvatuksen)

- valtio tukee (esim. vapaata sivistystyötä)

— valtio itse järjestää (esim. työllisyyskoulutusta)

Toisen maailmansodan jälkeen valtiovalta on säätänyt aikuiskasvatusta koskevia lakeja, jotka ovat koskeneet

- aikuiskasvatuksen rahoitusta

- aikuiskasvatuksen organisointia ja rakennetta

— aikuiskasvatuksen sisältöjä

Konferenssissa todettiin valtioiden poliittisen ja taloudellisen omavaraisuuden vaiheen päättyneen ja tilalle tulleen järjestelmän, jossa valtiot ovat yhä enemmän ja monin eri tavoin riippuvaisia toisistaan. Eurooppalaisten hyvinvointiyhteiskuntien synnyn ja kehityksen todettiin perustuneen yksityiselle aloitteellisuudelle ja pluralismille, jotka olivat tasapainossa valtion säätelyn kanssa. Nykyään tämä suhde tuntuu muuttuneen sellaiseksi, että julkisella vallalla on entistä voimakkaampi ote kaikkeen yhteiskunnalliseen toimintaan.

Koulutuspoliittisissa strategioissa on implisiittisesti hyväksytty lähtökohdaksi valtiovallan näkemysten primäärisyys, sillä niiden uskotaan olevan neutraaleja ja oi- keudenmukaisia koulutuksen suhteen. Tältä pohjalta on perinteinen näkemys liberalismiin perustuvasta pluralistisesta yhteiskuntaihanteesta muuttunut koulutuspolitiikassa monoliittiseksi ihanteeksi. Tämä tarkoittaa sitä, että koulutusja kasvatusjärjestelmistä tulee entistä useammin valtiovallan hallussa olevia organisaatioita, joiden tavoitteet ja opetussuunnitelmat ovat keskusjohtoisesti yhdenmukaistettuja. Tällöin katoavat valtionapujärjestelmät lähinnä yksityisille oppilaitoksille.

Euroopassa on nähtävissä se, että aikuiskasvatuksen avulla ei ole kyetty muuttamaan yhteiskunnallista todellisuutta. Se tapahtuu voimakkaampien yhteiskunnallisten järjestelmien kautta. Toisaalta on selvä usko ja kokemus siitä, että mahdollisimman suuri riippumattomuus viranomaisista toteuttaa parhaiten aikuiskasvatuksen perustehtävää (mikä se sitten onkaan!).

\section{Vertailevan aikuiskasvatuksen tehtävistä}

Keskeinen tehtävä on edelleen koota vertailukelpoista tilastoaineistoa kansainväliseen käyttöön. Jatkuva käsiteanalyysi on paikallaan samoin aikuiskasvatustutkimuksen teoreettisten lähtökohtien kansainvälinen vertailu.

Kansainvälisessä vertailussa ei riitä se, että löydetään yhtäläisyyksiä ja eroja aikuiskasvatuksen rakenteissa, toiminnassa, ongelmissa tai tarkoituksissa, vaan tulee pyrkiä selittämään mistä nämä erot ja yhtäläisyydet johtuvat ja mitä niistä seuraa.

Konferenssin loppuraportissa korostuu kaksi tutkimusteemaa: yleensä aikuiskasvatuksen historian tutkiminen sekä erityisesti valtiovallan ja aikuiskasvatuksen suhteen tutkiminen.

Ensimmäisestä teemasta konferenssissa kysyttiin mitä mieltä ylipäätään on tutkia aikuiskasvatuksen historiaa? Keitä muita se kiinnostaa kuin itse tutkijoita? Tällainen tutkimus edellyttää entistä useammin poikkitieteellisiä tutkimusotteita lähinnä sosiologian ja politologian suuntaan. Konferenssissa esitettyjen raporttien pohjalta voi havaita tutkijoiden kiinnostuk- sen kohdistuvan tälle vuosisadalle ja viime vuosikymmenelle. Erityisen kiinnostaviksi tutkimustehtäviksi todettiin aikuiskasvatuksen teorioiden ja niiden yhteiskunnallis-poliittisten kytkentöjen kehityksen selvittäminen sekä aikuiskasvatuksen käsitteistön historiallisen analyysin toteuttaminen.

Aikuiskasvatuksen ja valtiovallan välisen suhteen tutkimuksen todettiin tarvitsevan uusia metodologisia välineitä ja erilaisia malleja tämän suhteen analysoimiseksi.

Konferenssissa korostui tarve analysoida aikuiskasvatuksen roolia yhteiskunnallisessa ja poliittisessa muutoksessa. Tästä teemasta koottiin seuraavia tutkimusalueita:

- valtiovallan suhtautuminen aikuiskasvatukseen eri maissa ja valtioiden sisällä eri aikakausina,

- aikuiskasvatuksen suhde koulujärjestelmään valtion ohjannan, valvonnan ja rahoituksen suhteen,

- lainsäädännön ja muunlaisen julkisen vallan puuttumisen vaikutukset aikuiskasvatuksen toteuttamiseen,

- yksityisen ja julkisen sektorin osuus aikuiskoulutuksen rahoituksessa ja järjestämisessä,

- aikuiskasvatuksen rooli yhteiskunnallisessa kehityksessä, suhde nationalismiin, kansalliseen integraatioon, etnisten ja uskonnollisten vähemmistöjen asemaan,

- aikuiskasvatus poikkeustilanteissa kuten sodan ja vallankumouksen aikana,

- erilaisten kansalaisjärjestöjen toiminta aikuiskasvatuksen toteuttajina ja järjestöjen suhteet valtiovaltaan.

\section{Lopuksi}

Tämä konferensi vahvisti uskoani siihen, että suomalaisten aikuiskasvattajien tulee lisätä yhteyksiään kaikilla tasoilla muuhun maailmaan, mutta erityisesti Eurooppaan. Meillä on paljon annettavaa, mutta samalla meillä on enemmän opittavaa, ja opittavaa on nimenomaan aikuiskasvatuksen yhteiskuntasuhteista.

Vastaavanlainen konferenssi on tarkoitus järjestää 1990 joko Tsekkoslovakiassa, USA:ssa tai Israelissa. 